\title{
Biomass energy as a possibility for innovative agriculture initiatives
}

\author{
Ana Pimenta Ribeiro ${ }^{1,2}$ (1) $\cdot$ Silvio Dalmolin ${ }^{3}$ \\ ${ }^{1}$ CAPES Foundation, Ministry of Education of Brazil, Brasília, DF 70040-020, Brazil \\ ${ }^{2}$ Institute for Environmental Planning, Leibniz University of Hanover, 30419 Hanover, Germany \\ ${ }^{3}$ Solidda Energia, Pinhais, PR 83324-450, Brazil
}

Received: 16 May 2020/Revised: 23 October 2020/ Accepted: 26 October 2020/Published online: 12 November 2020

(C) The Author(s) 2020

\begin{abstract}
In searching for sustainable solutions for humans' necessities, clean and safe energy possibilities have been pursued. The objective of this research is to develop a procedure that improves the integration of renewable technologies into local planning processes. The methodology should be suitable for different contexts. The objective of this paper is to evaluate the potential of energy production through agricultural waste, ensuring the sustainability and development of clean technologies, the ideal allocation of the energy production unit, and the costs involved in the enterprise. The research hypothesis is that the potential for sustainable use of biomass can be identified and evaluated, thus showing the way for an improved energy plan for Brazil. The study area is within the Doce River Basin in Brazil. The methods developed in the study could be relevant for municipalities to record their potentials for energy production and pursue investments and local arrangements, promoting sustainable biomass energy generation. The results show that with proper investment, the energy generation through biomass residues could be viable and pay itself in a short amount of time, moreover in a scenario where the agricultural area is increased, growing the power generation capacity of a biomass power plant. The current agricultural production would cover $20 \%$ of the local energy demand.
\end{abstract}

Keywords Renewable energy $\cdot$ Biomass potential · Doce river basin $\cdot$ Spatial planning

Ana Pimenta Ribeiro

pimenta@umwelt.uni-hannover.de

\section{Introduction}

\subsection{Background}

As part of the United Nations sustainable development agenda, renewable energy is one of the goals for the sustainable use of our planet (United Nations 2015). As an example of a centralized source of power generation, the Brazilian case has hydropower as the energy source of almost $65 \%$ on the total energy supply and with an extremely centralized distribution system (EPE 2018). When there are risks of droughts, intensified by the climate change context (Hunt et al. 2018; Moran et al. 2018), natural gas thermoelectric energy still is seen as the alternative energy source (Corrêa da Silva et al. 2016; Zurn et al. 2017). Around $70 \%$ of the country's hydropower potential is located in the Amazon and Cerrado (Ferreira et al. 2014), the two biggest Brazilian biomes, both with a high level of endangerment. Negative impacts of these projects both on nature and on the way of life of the communities around the rivers are impossible to be avoided (Moran et al. 2018).

One way to reduce such negative effects is to use other renewable energies. Mainly considered by its diversity of possibilities in terms of origin and conversion technologies for energy products (McKendry , 2002a,b), biomass energy presents itself as a relevant player with potential for supplying renewable energy. The term biomass encompasses plant material produced through photosynthesis and all its by-products (Vidal and da Hora 2011). A substantial volume of research has already been developed on the topic in a diverse sort of regions such as Peru (Lillo et al. 2015), Spain (Díaz-Cuevas et al. 2019), Italy (Palmas et al. 2012), Greece (Skoulou et al. 2011), Germany (Palmas et al. 
2015), South Africa (Batidzirai et al. 2016), and Southern Asia (Bhattacharyya 2014). Responsible for $8 \%$ of the energy supply in Brazil (EPE 2018), previous studies on biomass energy production conclude that it should be considered on the advance of the country's energy sector. A national-wide methodology was presented in the Brazilian Atlas of Bioenergy (Coelho et al. 2012). There, it was considered residual energy production from agriculture and silviculture activities, liquid swine sewage, and solid urban waste in sanitary landfills.

Aiming to explore the potential as an energy source from agriculture, agroindustry, and livestock residues, the Rural Residues Energetic Inventory (EPE 2014) was produced by the EPE (Brazilian Energy Research Company). Different sources were presented, detailing the agriculture production and the estimation of its residues. A potential of 48 million toe (Tonnes of oil equivalent, 1 toe $=11.63$ megawatt-hour) for agriculture and livestock waste was estimated, considering different conversion technologies.

Another example of Brazilian biomass energy potential assessment is the BREA Project (GBIO et al. 2015). A complete dataset on energy generation from residues was presented, with the objective of developing "a better knowledge of energy requirements for productive purposes among poor households in urban and rural areas of Brazil and Colombia (many of them in isolated regions), which could allow inputs for targeted policy interventions" (GBIO et al. 2015, p. 23). The methodology included an exploration of different technologies for conversion, potentials, policies, scenarios, and barriers to the development of bioenergy in the Brazilian Amazonian region.

Regarding other renewable energy sources, biomass could be related to a potential conflict with other land uses (Söderberg and Eckerberg 2013), and it requires the major area per produced energy unit (Blaschke et al. 2013a). Without taking into account careful planning, the competition between biomass energy, conservation, agriculture, and forestry is predictable (Blaschke et al. 2013b). Concerning sustainability, any enterprise that seeks biomass as a source of power must guarantee the soil health, the biodiversity, and the water cycle.

One possibility for minimizing adverse environmental impacts of biomass use is to produce energy from residues. Several agricultural systems base their natural cycle on nutrient cycling, where part or particular residue of the main crop is left on the soil, to protect it physically from rain, sun, and wind and to nurture soil biota (Hobbs et al. 2008; Sommer et al. 2018). This operation can avoid the need for adding fertilizers, protecting the soil against degradation and increasing the carbon sequestration. Some researches indicate that there is no need to place all the available residues on the soil. In some cases, a proportion can be removed without causing harm to the integrity of the soil (Dias et al. 2012; EPE 2014; Foelkel 2016).

Against this background, the use of residual biomass can contribute to energy system transformation in Brazil (Ribeiro and Rode 2016) and at the same time reduce the negative effects resulting from the policy focus on the use of water for electricity generation in Brazil (EPE 2017). To drive this process forward, a spatial approach is needed to improve the integration of renewable technologies into regional and local processes by combining renewable energy potentials with environmental protection issues. Therefore, the objective of this paper is to evaluate the potential of energy production through agricultural waste, ensuring the sustainability and development of clean technologies, the ideal allocation of the energy production unit, and the costs involved in the enterprise.

\subsection{Study area}

Based on previous studies (Ribeiro and Rode 2016, 2019), the Brazilian area chosen to be the focus of the analysis should be within the state of Minas Gerais. A study area was selected encompassing 16 municipalities in the Doce River Basin (Fig. 1), Brazil. At the end of 2015, a humanenvironmental catastrophe occurred with the rupture of a mining tailings dam, spilling 62 million cubic meters of tailings along the river, damaging over $680 \mathrm{~km}$, until they reached the ocean (Borges 2018).

The impact has altered thousands of lives profoundly, disturbing the economy of the affected cities in the states of Minas Gerais and Espírito Santo. The number of affected people is challenging to reach, but the estimation is that the population living at the Doce River Basin was around 3.2 million inhabitants. Nineteen people have died, and it is estimated that up to 500,000 people have been affected (Wallauer 2018), including communities of fishermen, indigenous and farmers, who rely on that water to live.

Many initiatives have been carried out to create new opportunities for people affected by the dam rupture in different parts of the basin. In this context, it was pursued innovative initiatives for agriculture in the municipalities surrounding the Doce River State Park. One possibility proposed to the communities was to increase the plantation area, using the agricultural waste for electricity production.

The objective of this paper is to evaluate the potential of energy production through agricultural waste, ensuring the sustainability and development of clean technologies, the ideal allocation of the energy production unit, and the costs involved in the enterprise. 


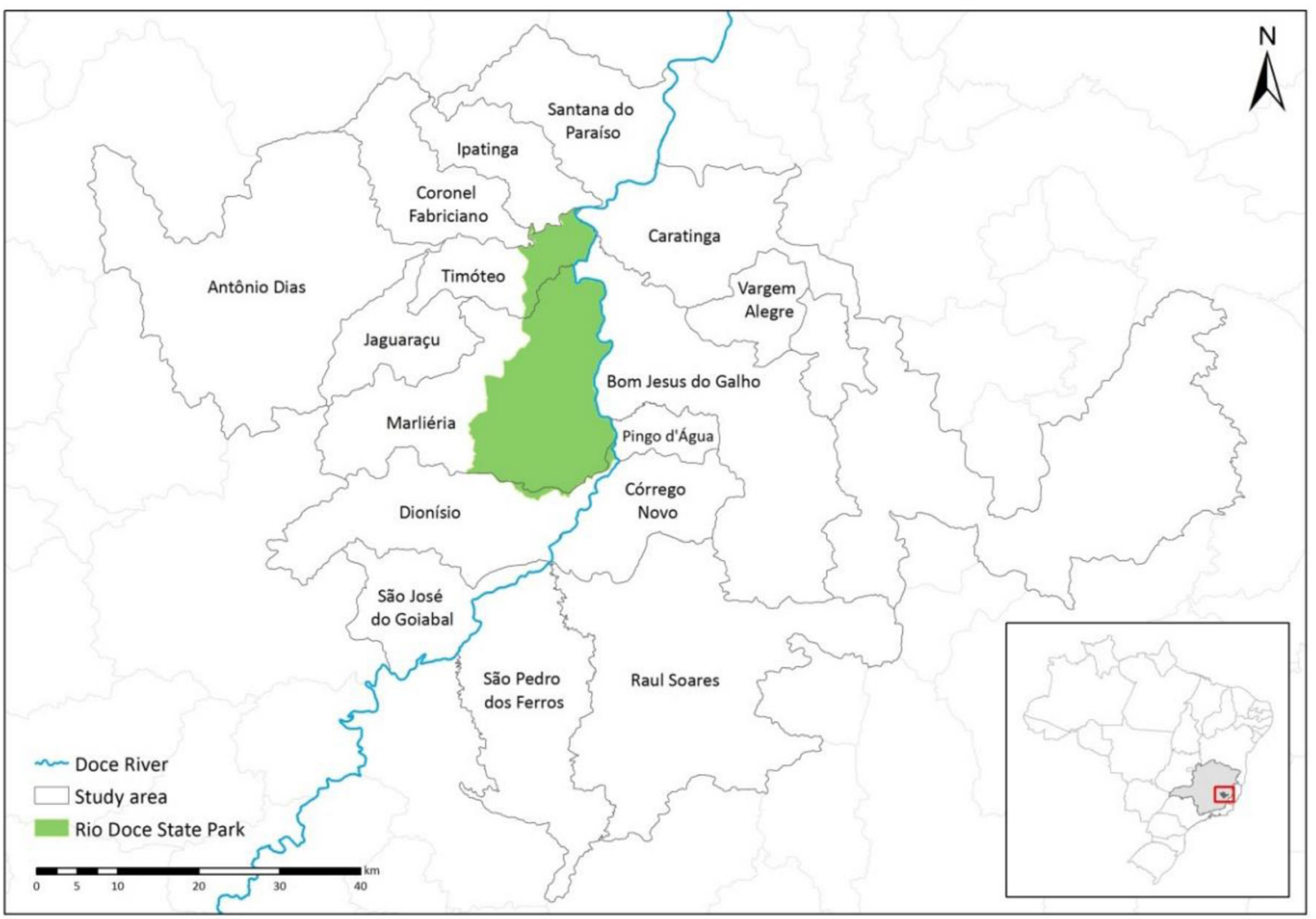

Fig. 1 Municipalities included in the analysis. Source: IBGE (2015)

\section{Materials and methods}

\subsection{Productivity data analysis}

For the investigations two scenarios were evaluated: one considering the production data from 2017 and the other with an increase in production on the crops indicated by the population, reaching the maximum limit of the project viability.

Data were collected from the governmental statistics (SIDRA - IBGE 2015) considering the crops of interest for the local population, in order to assess the distribution of biomass residues. In previous workshops conducted by UFMG researchers, the population was consulted about which crops they would like to expand the cultivation area. The chosen crops were corn, beans, manioc, and sugarcane. The assessment of production data is vital for the estimation of the amount of residues generated during the production process. For all the crops, the literature indicates a percentage of rests remaining from harvesting or primary processing.

Considering soil health as the central necessity for the continuation of production activities for crops, the recommendations in the literature regarding the percentage of the residues that should be left in the field for soil recovery was followed. This factor was selected as an indicator for a good ecological status. A sustainable technical coefficient $\left(\mathrm{TC}_{\mathrm{S}}\right.$ ) was adopted to estimate the energy productivity (see Table 1). The traditional technical coefficient $\left(\mathrm{TC}_{\mathrm{T}}\right)$ represents the proportion of residues within the total yield (Coelho et al. 2015). For each of the crops, literature was found indicating how much could be used to maintain the soil health. For all the sources, a percentage indicated by studies in Brazil, adequate for the tropical conditions, was adopted. In this paper, it was considered that the guarantee of supply for bioenergy production depends directly on soil productivity. A more conservative coefficient was adopted in order to guarantee sustainability due to conserving the soil humus content. Table 1 represents the values of $\mathrm{TC}_{\mathrm{S}}$ used in the calculation.

\subsection{Application of formulas}

To calculate the amount of energy that could be produced, considering the losses in the process, we applied different formulas to different sources. All the formulas were used by Coelho et al. (2012) and Ribeiro and Rode (2019). The calculation results inform how biomass energy is distributed in the region.

Crops the conversion efficiency adopted for the residues was $15 \%$, of the low thermodynamic yield -20 bar boiler 
Table 1 Traditional technical coefficient and sustainable technical coefficient

\begin{tabular}{lllll}
\hline Source & Type of residue & $\begin{array}{l}\text { Traditional technical } \\
\text { coefficient }\end{array}$ & $\begin{array}{l}\text { Percentage left } \\
\text { on the soil (\%) }\end{array}$ & $\begin{array}{l}\text { Sustainable technical } \\
\text { coefficient }\end{array}$ \\
\hline Sugarcane & Straw & 0.20 & 50 & 0.1 \\
Beans & Husk & 1.16 & 60 & 0.45 \\
Manioc & Aerial & 0.65 & 60 & 0.25 \\
Corn & Stover & 1.68 & 60 & 0.65 \\
\hline
\end{tabular}

The $\mathrm{TC}_{\mathrm{T}}$ and $\mathrm{TC}_{\mathrm{S}}$ for beans, manioc, and corn were found on EPE (2014). For sugarcane, the coefficient adopted was from Dias et al. (2012).

compound systems, atmospheric condenser turbine (GBIO et al. 2015) and was estimated by Eq. 1, as follows:

Potential $=\frac{\left[\left(\mathrm{Crops}_{\mathrm{tons}} \cdot \mathrm{TC}\right) \cdot \mathrm{LHV}_{\mathrm{kcal} / \mathrm{kg}} \cdot 0.15\right]}{\left(860 \cdot 8322_{\mathrm{hours}}\right)}$,

where the Potential is given in MW/year, $\mathrm{Crops}_{\text {tons }}$ is the total of harvested crops in a year, TC is the technical coefficient, LHV the lower heating value. The value 0.15 corresponds to $15 \%$ conversion efficiency, 860 is the conversion factor from $\mathrm{kcal} / \mathrm{kg}$ to $\mathrm{kWh} / \mathrm{kg}$ and 8322 the working hours per year, considering that the energy would be produced in $95 \%$ of the year's hours. This factor converts the results from megawatt-hour to megawatts per year.

Sugarcane the potential (MW/year) was estimated by the calculation given in Eq. 2 and was made for simple systems; we considered the lower energetic yield of $30 \mathrm{~kW} /$ sugarcane tons.

Potential $=\frac{\left(\text { Sugarcane }_{\text {tons }} \cdot 30_{\mathrm{kWh} / \text { ton }}\right)}{\left(1000 \cdot 5563_{\text {hours }}\right)}$,

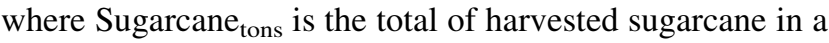
year, $30 \mathrm{kWh} /$ ton the energetic yield of sugarcane in cogeneration systems, 1000 the conversion from $\mathrm{kW}$ to $\mathrm{MW}$ and 5563 the working hours from April to November (considering the harvesting time). This factor is important to convert the results from megawatt-hour to megawatts per year.

Wood the potential (MW/year) was estimated by Eq. 3 and considered for a conventional steam turbine system (Rankine cycle) with yields of $15 \%$, considering a smallsized system.

Potential $=\frac{\left[\left(\text { Wood }_{\text {tons }} \cdot \mathrm{TC}\right) \cdot \mathrm{LHV}_{\mathrm{kcal} / \mathrm{kg}} \times 0.15\right]}{\left(860 \cdot 8322_{\mathrm{hours}}\right)}$,

where Wood $_{\text {tons }}$ corresponds to the total of harvested wood in a year, TC is the technical coefficient, the proportion of residues in the total yield, LHV the lower heating value. The number 0.15 corresponds to the $15 \%$ conversion efficiency, 860 is the conversion factor from $\mathrm{kcal} / \mathrm{kg}$ to $\mathrm{kWh} /$ $\mathrm{kg}$ and 8322 are the working hours per year, considering that the energy would be produced in $95 \%$ of the year's hours. This factor converts the results from megawatt-hour to megawatts per year.

The entire calculation was made, taking into consideration a viable technology: a standard technology with low conversion efficiency (15\%). Considering that investing in sustainable energy to improve people's lives is not necessarily an attractive business, as well as the economic downturn that Brazil is facing, environmental issues are not a priority (Escobar 2018). Modern and expensive technology with a higher conversion coefficient would be too far from reality.

\subsection{Demand estimation}

The demand for the municipalities was considered as the monthly average consumption per residence on the state (Reis and Reis 2017), assessed by the local energy company, CEMIG. The value applied for the study area is 150 $\mathrm{kWh} /$ month per capita.

\subsection{Implementation costs}

The calculation considered the specific fuel consumption of $2.00 \mathrm{t} / \mathrm{MWh}$ (net). This value comes from the thermal balance of the plant, estimated according to Rankine's power cycle methodology (Moran and Shapiro 2000).

The current market prices from October 2018 were applied for the calculation, carried out by Solidda Energia (Solidda Energia 2019), a company that operates in thermoelectric power generation with biomass area in the country. As the methodology for those calculations is property from a private company, it was not possible to describe the exact formulas and procedures. The calculation of the total investment was based on the company's cost assessment, which operates manufacturing plants: purchase of raw material, processing, and assembly of all equipment.

The idea of a better local arrangement was the creation of a cooperative system between municipalities in the region, to distribute the energy among all of them. Thus, the price of energy produced by the power plant-which is part of the cooperative-would be the same price that 
industries would buy from CEMIG (the region's energy concessionaire). The cooperative industries would stop buying from CEMIG and start consuming the energy generated by their cooperative. The amount of 80 US\$ was originally applied, but in CEMIG's website, the value of MWh for industrial/commercial consumers is $95 \mathrm{US} \$$ / MWh (CEMIG 2018). For industries to enter the cooperative they must have some advantage, so the value of the tariff was reduced from 95 US\$ to 80 US\$/MWh.

\section{Results}

Being large and somewhat industrialized cities, three out of the 16 evaluated municipalities were not analyzed due to its irrelevant agricultural production (Fig. 2).

Together, the 13 analyzed municipalities presented a production capable of meeting about $20 \%$ of local demand (Table 2). The values had an extensive range of variability, with an emphasis on São Pedro dos Ferros, a place where agricultural waste is enough to meet $329 \%$ of the intern energy demand.

\subsection{Implementation costs}

The analysis of the implementation costs took into consideration the most efficient arrangement for residues transportation logistics and resulted in a setting where it would be built two power plants, on the municipalities of São Pedro dos Ferros and Marliéria (Table 3). As shown in Fig. 2, the study area was divided into municipalities that would supply residues to the Marliéria Power Plant (MP) and São Pedro dos Ferros Power Plant (SPFP).

It was considered an operation as an energy cooperative, distributing energy through the Resolution of the Distributed Generation 482/687-RDG (Brasil and ANEEL 2012). The farmers themselves could consume the energy produced with the waste. In this case, the average price of 78 US\$/MWh was applied, which would be the purchase price of the energy if the consumers would buy directly from the energy company, CEMIG. Considering selling on the market, the price would be from 40 to 50 US $\$ / M W h$.

Even presenting significant potential for biomass energy production, the municipality of Caratinga figures as a supplier municipality, and cannot be considered as a potential host of a power plant. As the calculations of power plants locations were developed considering the best spatial arrangement for the entire area, the costs of the

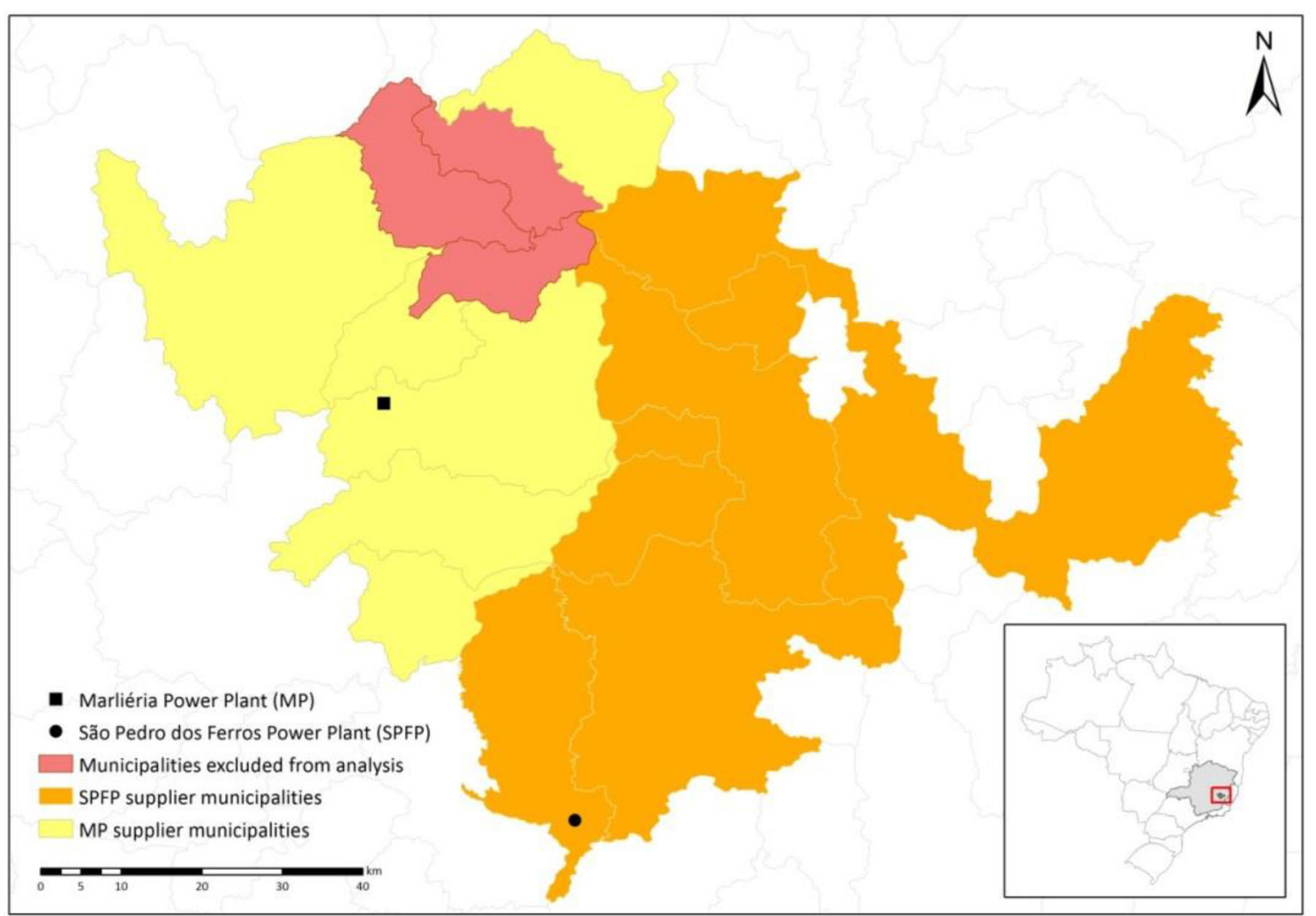

Fig. 2 Results from the viability analysis and power plants location: Marliéria Power Plant (MP) and São Pedro dos Ferros Power Plant (SPFP). Source: IBGE (2015) 
Table 2 Energy potential of agricultural waste versus average annual energy consumption

\begin{tabular}{|c|c|c|c|c|c|}
\hline Municipality & $\begin{array}{l}\text { Energy potential } \\
\text { (MW/year) }\end{array}$ & $\begin{array}{l}\text { Energy potential } \\
(\mathrm{kW} \mathrm{h} \text { /year) }\end{array}$ & $\begin{array}{l}\text { Average annual } \\
\text { energy consumption } \\
(\mathrm{kW} \mathrm{h/year)}\end{array}$ & $\begin{array}{l}\text { Potential-average } \\
\text { consumption } \\
(\mathrm{kW} \mathrm{h/year)}\end{array}$ & $\begin{array}{l}\text { Percentage } \\
\text { of the total } \\
\text { demand }(\%)\end{array}$ \\
\hline Antônio Dias & 0.02 & $177,085.47$ & $5,173,200$ & $-4,996,115$ & 3 \\
\hline Bom Jesus do Galho & 0.16 & $1,294,496.51$ & $8,674,200$ & $-7,379,307$ & 15 \\
\hline Caratinga & 0.39 & $3,255,043.60$ & $47,986,200$ & $-44,729,126$ & 7 \\
\hline Córrego Novo & 0.05 & $377,773.26$ & $1,794,600$ & $-1,416,330$ & 21 \\
\hline Dionísio & 0.06 & $464,133.14$ & $4,766,400$ & $-4,301,502$ & 10 \\
\hline Jaguaraçu & 0.02 & $130,037.79$ & $1,598,400$ & $-1,468,074$ & 8 \\
\hline Marlieria & 0.09 & $759,236.34$ & $2,239,200$ & $-1,477,973$ & 34 \\
\hline Pingo d'Agua & 0.03 & $269,968.60$ & $2,341,800$ & $-2,071,044$ & 12 \\
\hline Raul Soares & 0.20 & $1,635,343.60$ & $13,887,000$ & $-12,246,292$ & 12 \\
\hline Santana do Paraiso & 0.04 & $297,671.51$ & $14,203,800$ & $-13,905,153$ & 2 \\
\hline São Jose do Goiabal & 0.17 & $1,430,795.93$ & $3,115,800$ & $-1,679,430$ & 46 \\
\hline São Pedro dos Ferros & 1.80 & $15,016,480.47$ & $4,566,600$ & $10,512,865$ & 329 \\
\hline \multirow[t]{2}{*}{ Vargem Alegre } & 0.02 & $207,265.12$ & $3,668,400$ & $-3,460,155$ & $6 \%$ \\
\hline & 3.04 & $25,315,331$ & $114,015,600$ & $-88,617,636$ & $22 \%$ \\
\hline
\end{tabular}

Table 3 Costs involved in the implementation of two power plants covering $20 \%$ of the region's energy demand

\begin{tabular}{|c|c|c|c|c|c|}
\hline Power Plant & $\begin{array}{l}\text { Capacity } \\
\text { (MW) }\end{array}$ & $\begin{array}{l}\text { Investment } \\
\text { (US\$) }\end{array}$ & $\begin{array}{l}\text { Deadline for } \\
\text { implementation (years) }\end{array}$ & $\begin{array}{l}\text { Net income from energy } \\
\text { sales (US\$/year) }\end{array}$ & $\begin{array}{l}\text { Investment } \\
\text { return (years) }\end{array}$ \\
\hline São Pedro dos Ferros & 2.90 & $4,240,000$ & 1.50 & $1,241,500$ & 3.42 \\
\hline Marliéria & 0.43 & $1,060,000$ & 1.00 & 72,800 & 14.56 \\
\hline
\end{tabular}

collection logistics and material transportation were favorable for the installation on the municipality of Marliéria.

\subsection{Future scenarios}

Three scenarios of an increase in local production were assembled: meeting $50 \%, 70 \%$, and $100 \%$ of local demand for electricity (Table 4). For the increase in production, only the crops of interest for expansion by the local population were considered.

To attend $100 \%$ of the demand, it would be necessary two power plants with a $7 \mathrm{MW}$ capacity. Above $5 \mathrm{MW}$ (gross power), it is not possible for the enterprise to meet the requirements of the RDG, and only the sale in the free market is possible. The $7 \mathrm{MW}$ power plant, for example, would have an average monthly financial loss of 9,000 US\$. Thus, the best option is to disregard economically unviable units, whose power is higher than $5 \mathrm{MW}$.

The calculation of the costs took into consideration the scenario covering $70 \%$ of the local demand and the maximum viable production of $5 \mathrm{MW}$ (Table 5).

\section{Discussion}

Studies, such as Portugal-Pereira et al. (2015), Ribeiro and Rode (2016), and Teixeira et al. (2018), show the vast potential of Brazil to generate energy through agricultural residues. Another common point of the three studies is to point out future analysis that takes into consideration the particularities of a determined site, being able to more accurately calculate the costs and potentialities involved. This step was taken in this paper.

The methodology, used previously in Amazonian municipalities (Coelho et al. 2015), presents a feasible approach for the estimation of biomass potential, considering the losses involved in the process. This methodology was also applied by Ribeiro and Rode (2019) in a different region of the state of Minas Gerais. As a result, they found out that the energy potential from residual biomass could be enough to attend the local demand there. Those cases, among others (like Portugal-Pereira et al. (2015) in Brazil, Vergara et al. (2020) in Colombia or Famoso et al. (2020) in Italy), reveal a potential that should be explored more thoroughly, creating opportunities for diversification on the 
Table 4 Production increment scenarios directed to attend local energy demands

\begin{tabular}{|c|c|c|c|c|c|c|c|c|c|c|c|c|c|}
\hline \multicolumn{4}{|l|}{ Beans } & \multicolumn{4}{|l|}{ Manioc } & \multicolumn{5}{|l|}{ Corn } & \\
\hline $\begin{array}{l}\text { Average } \\
\text { yield } \\
\text { (ton/ha) }\end{array}$ & $50 \%$ & $70 \%$ & $100 \%$ & $\begin{array}{l}\text { Average } \\
\text { yield } \\
\text { (ton/ha) }\end{array}$ & $50 \%$ & $70 \%$ & $100 \%$ & $\begin{array}{l}\text { Average } \\
\text { yield } \\
\text { (ton/ha) }\end{array}$ & $50 \%$ & $70 \%$ & $100 \%$ & $\begin{array}{l}\text { Scenarios } \\
100 \%\end{array}$ & \\
\hline \multirow[t]{2}{*}{0.72} & 30,718 & 43,006 & 61,437 & 12.68 & 5,394 & 7,552 & 10,789 & 3.03 & 38,722 & 54,211 & 77,445 & 149,670 & Total hectares \\
\hline & 17,077 & 29,365 & 47,796 & & 2,999 & 5,157 & 8,393 & & 21,527 & 37,016 & 60,249 & 116,438 & $\begin{array}{l}\text { Increased } \\
\text { hectares }\end{array}$ \\
\hline
\end{tabular}

Table 5 Costs involved in the implementation of two power plants covering $70 \%$ of the region's energy demand

\begin{tabular}{|c|c|c|c|c|c|}
\hline Power plant & $\begin{array}{l}\text { Capacity } \\
\text { (MW) }\end{array}$ & $\begin{array}{l}\text { Investment } \\
\text { (US\$) }\end{array}$ & $\begin{array}{l}\text { Deadline for } \\
\text { implementation (years) }\end{array}$ & $\begin{array}{l}\text { Net income from energy } \\
\text { sales (US\$/year) }\end{array}$ & $\begin{array}{l}\text { Investment } \\
\text { return (years) }\end{array}$ \\
\hline São Pedro dos Ferros & 5.00 & $6,625,000$ & 1.50 & $2,039,000$ & 3.25 \\
\hline Marliéria & 5.00 & $6,625,000$ & 1.50 & $2,120,600$ & 3.12 \\
\hline
\end{tabular}

energy matrix and therefore a safer energy system in Brazil. The current agricultural production would cover around $20 \%$ of the local energy demand in the studied area.

A closer assessment in the municipalities, such as the one conducted by Kishita et al. (2017) in Japan, analyzing the local demand, more accurate data on the local yield could bring a complete set of information to build the analysis. Also, in the next step, the quality of the local production and the possibilities of storage should be assessed, as presented in Famoso et al. (2020). Even though this result already points to an interesting outcome, where the diversification of the energy matrix can move toward a sustainable path.

São Pedro dos Ferros stands out for its high productivity, to the point of enabling the installation of a power plant in its area. The primary source of waste of the municipality is sugarcane, which even without the increase in its production in future scenarios remains the largest producer of energy in the region. Been the cheapest and most common source of biomass energy in the country (Leal et al. 2013; Corrêa da Silva et al. 2016), sugarcane plays an essential role in this scenario.

The time for the investment return drops significantly on the $70 \%$ scenario, foremost on the Marliéria power plant. As power generation capacity increases, the costs involved in implementing the power plant pays faster the investment. The increase in agricultural crop areas needs to be limited to local environmental constraints, as shown in Ribeiro and Rode (2016) and Teixeira et al. (2018). Considering that it is a region around a protected area, a spatial planning study for allocation of these new agricultural areas should be developed and presented to the communities in an action plan.

In October 2018, a workshop to present a comprehensive study on possible technological innovations to be applied in the region was held with the population and decision-makers of the studied municipalities. The results of this study were presented there, but it did not figure as a choice of the locals for their future development. A more in-depth work should be conducted with the local population of the region, focusing specifically on the theme of biomass energy and its possibilities. It may provide thrilling inputs for the continuation of this research.

\section{Conclusions}

This paper explores opportunities for energy generation through biomass residues and the costs involved in the initiative. The study area is a region affected by a humanenvironmental catastrophe, which led its communities to explore the possibilities for innovative agriculture initiatives.

The results show that, even though a significant investment is required, the energy generation through biomass residues could be viable and pay itself in a short amount of time. This statement is even more applicable in a scenario where the agricultural area is increased, growing the power generation capacity of a biomass power plant. Thus, bioenergy from agricultural residues could figure as an innovative initiative for agriculture in the study area. 
The methods developed in the study presented here could be relevant for municipalities to record their potentials for energy production from residual biomass and seek for investments and local arrangements, depending on their potentials and affinities, in order to promote biomass energy generation. Working together, the municipalities can generate energy and create better power availability, jobs, income, and more opportunities for energy decentralization. It could be used by public or private initiative, as a basis for projects aimed at sustainable energy development. Further studies should elaborate spatial limitations for the agricultural expansion and modeling scenarios where environmental constraints are respected. The input of the population on the matter is also fundamental for the continuity of such a biomass energy project.

Acknowledgements We want to thank Sónia M. Carvalho Ribeiro for the information given on the local population; Michael Rode and Sylvia Herrmann for the valuable comments.

Author contributions APR contributed to conceptualization, methodology, analysis on bioenergy potential, and writing, review and editing; SD contributed to analysis on costs and power plants unities allocation.

Funding Open Access funding enabled and organized by Projekt DEAL. This research is fully financed by the Brazilian research incentive program Science Without Borders, from the Coordenação de Aperfeiçoamento de Pessoal de Nível Superior (CAPES Foundation, Proc. n BEX 12957/13-5) and a doctorate research project from the Institute of Environmental Planning (Institut für Umweltplanung-IUP), the Leibniz Universität Hannover.

Availability of data and material The datasets analyzed during the current study are available in the SIDRA (Brazilian Institute of Statistic and Geography Automatic Recovery System) repository, at https://sidra.ibge.gov.br. The datasets generated during the current study are available from the author on reasonable request.

\section{Compliance with ethical standards}

Conflict of interest The authors declare that they have no conflict of interest.

Open Access This article is licensed under a Creative Commons Attribution 4.0 International License, which permits use, sharing, adaptation, distribution and reproduction in any medium or format, as long as you give appropriate credit to the original author(s) and the source, provide a link to the Creative Commons licence, and indicate if changes were made. The images or other third party material in this article are included in the article's Creative Commons licence, unless indicated otherwise in a credit line to the material. If material is not included in the article's Creative Commons licence and your intended use is not permitted by statutory regulation or exceeds the permitted use, you will need to obtain permission directly from the copyright holder. To view a copy of this licence, visit http://creativecommons. org/licenses/by/4.0/.

\section{References}

Batidzirai B, Valk M, Wicke B, Junginger M, Daioglou V, Euler W, Faaij APC (2016) Current and future technical, economic and environmental feasibility of maize and wheat residues supply for biomass energy application: illustrated for South Africa. Biomass Bioenerg 92:106-129. https://doi.org/10.1016/j.biom bioe.2016.06.010

Bhattacharyya SC (2014) Viability of off-grid electricity supply using rice husk: a case study from South Asia. Biomass Bioenergy 68:44-54. https://doi.org/10.1016/j.biombioe.2014.06.002

Blaschke T, Biberacher M, Gadocha S, Schardinger I (2013a) 'Energy landscapes': meeting energy demands and human aspirations. Biomass Bioenergy 55:3-16. https://doi.org/10.1016/j.biombioe. 2012.11.022

Blaschke T, Biberacher M, Gadocha S, Schardinger I (2013b) "Energy landscapes": meeting energy demands andhuman aspirations. Biomass Bioenergy 55:3-16. https://doi.org/10. 1016/j.biombioe.2012.11.022

Borges S (2018) The Tailings dam disaster in Mariana, Minas Gerais: socio-environmental and management aspects of mining resources exploration. Cuad Geogr Rev Colomb Geogr 27:301-312. https://doi.org/10.15446/rcdg.v27n2.63008

Brasil, ANEEL (2012) Resolução Normativa $N^{\circ} 482$ de 17 de Abril de 2012. In: April 17. https://www2.aneel.gov.br/cedoc/ ren2012482.pdf. Accessed 23 Jan 2019

CEMIG (2018) Revisão Cadastral de Benefícios Tarifários Rural. https://www.cemig.com.br/pt-br/atendimento/Paginas/valores_ de_tarifa_e_servicos.aspx. Accessed 8 Mar 2020

Coelho ST, Monteiro MB, Karniol MR (2012) Atlas de Bioenergia do Brasil. São Paulo

Coelho ST, Sanches-Pereira A, Tudeschini LG et al (2015) Biomass residues as electricity generation source in low HDI regions of Brazil. In: XI Latin-American congress on electricity generation and transmission-CLAGTEE 2015, p 8

Corrêa da Silva R, de Marchi NI, Silva Seifert S et al (2016) Electricity supply security and the future role of renewable energy sources in Brazil. Renew Sustain Energy Rev 59:328-341. https://doi.org/10.1016/j.rser.2016.01.001

Dias JMCDS, de Souza DT, Braga M et al (2012) Produção de briquetes e péletes a partir de resíduos agrícolas, agroindustrais e florestais. Embrapa Agroenergia, Brasília

Díaz-Cuevas P, Domínguez-Bravo J, Prieto-Campos A (2019) Integrating MCDM and GIS for renewable energy spatial models: assessing the individual and combined potential for wind, solar and biomass energy in Southern Spain. Clean Technol Environ Policy. https://doi.org/10.1007/s10098-01901754-5

EPE (2014) Inventário Energético de Resíduos Rurais. Rio de Janeiro EPE (2018) Brazilian energy balance 2018lyear 2017. Rio de Janeiro

Escobar H (2018) Scientists, environmentalists brace for Brazil's right turn. Science 362:273-274. https://doi.org/10.1126/science. 362.6412 .273

Famoso F, Prestipino M, Brusca S, Galvagno A (2020) Designing sustainable bioenergy from residual biomass: site allocation criteria and energy/exergy performance indicators. Appl Energy 274:115315. https://doi.org/10.1016/j.apenergy.2020.115315

Ferreira J, Aragao LEOC, Barlow J et al (2014) Brazil's environmental leadership at risk. Science 346:706-707. https://doi.org/ $10.1126 /$ science. 1260194

Foelkel C (2016) Utilização da Biomassa do Eucalipto para Produção de Calor, Vapor e Eletricidade-Parte 3: Resíduos Florestais Energéticos Celso. In: Eucalyptus Online Book-Capítulo, p 45

GBIO, GNESD, COPPE, IEE-USP (2015) Biomass residues as energy source to improve energy access and local economic 
activity in low HDI regions of Brazil and Colombia (BREA). São Paulo

Hobbs PR, Sayre K, Gupta R (2008) The role of conservation agriculture in sustainable agriculture. Philos Trans R Soc Lond B Biol Sci 363:543-555. https://doi.org/10.1098/rstb.2007.2169

Hunt JD, Stilpen D, de Freitas MAV (2018) A review of the causes, impacts and solutions for electricity supply crises in Brazil. Renew Sustain Energy Rev 88:208-222. https://doi.org/10.1016/ J.RSER.2018.02.030

Kishita Y, Nakatsuka N, Akamatsu F (2017) Scenario analysis for sustainable woody biomass energy businesses: the case study of a Japanese rural community. J Clean Prod 142:1471-1485. https://doi.org/10.1016/j.jclepro.2016.11.161

Leal MRLV, Galdos MV, Scarpare FV et al (2013) Sugarcane straw availability, quality, recovery and energy use: a literature review. Biomass Bioenergy 53:11-19. https://doi.org/10.1016/j.biom bioe.2013.03.007

Lillo P, Ferrer-Martí L, Boni A, Fernández-Baldor Á (2015) Assessing management models for off-grid renewable energy electrification projects using the Human Development approach: case study in Peru. Energy Sustain Dev 25:17-26. https://doi. org/10.1016/j.esd.2014.11.003

McKendry P (2002a) Energy production from biomass (part 1): overview of biomass. Bioresour Technol 83:37-46

McKendry P (2002b) Energy production from biomass (part 2): conversion technologies. Bioresour Technol 83:47-54. https:// doi.org/10.1016/S0960-8524(01)00119-5

Moran EF, Lopez MC, Moore N et al (2018) Sustainable hydropower in the 21st century. Proc Natl Acad Sci USA. https://doi.org/10. 1073/pnas. 1809426115

Moran MJ, Shapiro HN (2000) Princípios de termodinâmica para engenharia, 4th edn. Wiley \& Sons Inc, New York

Palmas C, Abis E, von Haaren C, Lovett A (2012) Renewables in residential development: an integrated GIS-based multicriteria approach for decentralized micro-renewable energy production in new settlement development: a case study of the eastern metropolitan area of Cagliari, Sardinia. Italy Energy Sustain Soc 2:10. https://doi.org/10.1186/2192-0567-2-10

Palmas C, Siewert A, von Haaren C (2015) Exploring the decisionspace for renewable energy generation to enhance spatial efficiency. Environ Impact Assess Rev 52:9. https://doi.org/10. 1016/j.eiar.2014.06.005

Portugal-Pereira J, Soria R, Rathmann R et al (2015) Agricultural and agro-industrial residues-to-energy: Techno-economic and environmental assessment in Brazil. Biomass Bioenerg 81:521-533. https://doi.org/10.1016/J.BIOMBIOE.2015.08.010
Reis RJ dos, Reis LS dos (2017) Atlas da biomassa de Minas Gerais. Belo Horizonte

Ribeiro AP, Rode M (2016) Spatialized potential for biomass energy production in Brazil: an overview. Brazilian J Sci Technol 3:13. https://doi.org/10.1186/s40552-016-0037-0

Ribeiro AP, Rode M (2019) Residual biomass energy potential: perspectives in a peripheral region in Brazil. Clean Technol Environ Policy. https://doi.org/10.1007/s10098-019-01675-3

SIDRA - IBGE (2015) Produção Agrícola Municipal. https://sidra. ibge.gov.br/pesquisa/pam/tabelas. Accessed 16 Oct 2016

Skoulou V, Mariolis N, Zanakis G, Zabaniotou A (2011) Sustainable management of energy crops for integrated biofuels and green energy production in Greece. Renew Sustain Energy Rev 15:1928-1936. https://doi.org/10.1016/j.rser.2010.12.019

Söderberg C, Eckerberg K (2013) Rising policy conflicts in Europe over bioenergy and forestry. For Policy Econ 33:112-119. https://doi.org/10.1016/j.forpol.2012.09.015

Energia S (2019) Sistemas de Geração de Energia. Turbinas a Vapor, Painéis Elétricos

Sommer R, Paul BK, Mukalama J, Kihara J (2018) Reducing losses but failing to sequester carbon in soils- the case of Conservation Agriculture and Integrated Soil Fertility Management in the humid tropical agro-ecosystem of Western Kenya. Agric Ecosyst Environ 254:82-91. https://doi.org/10.1016/J.AGEE.2017.11. 004

Teixeira TR, Soares Ribeiro CAA, Rosa dos Santos A et al (2018) Forest biomass power plant installation scenarios. Biomass Bioenerg 108:35-47. https://doi.org/10.1016/j.biombioe.2017. 10.006

United Nations (2015) Transforming our world: the 2030 Agenda for Sustainable Development

Vergara JC, Rojas G, Ortegon K (2020) Sugarcane straw recovery for bioenergy generation: a case of an organic farm in Colombia. ACS Omega 5:7950-7955. https://doi.org/10.1021/acsomega. $9 \mathrm{~b} 04340$

Vidal ACF, da Hora AB (2011) Perspectivas do setor de biomassa de madeira para a geração de energia. Pap e Celul 261-314

Wallauer J, (host) (2018) Mamilos 159 - Rio Doce - Da Lama ao Caos. In: Audio Pod. https://www.b9.com.br/95832/mamilos159-rio-doce-da-lama-ao-caos/. Accessed 29 Aug 2018

Zurn HH, Tenfen D, Rolim JG et al (2017) Electrical energy demand efficiency efforts in Brazil, past, lessons learned, present and future: a critical review. Renew Sustain Energy Rev 67:1081-1086. https://doi.org/10.1016/j.rser.2016.09.037 